\title{
INTRAVENOUS LIDOCAINE AS A SUPPLEMENT TO NITROUS OXIDE ANAESTHESIA FOR RADICAL MIDDLE EAR SURGERY
}

\author{
J. ANTonio ALdrete, M.D. ANd John G. Fraser, M.D.*
}

THIS IS A PRELIMINARY REPORT of our experience employing intravenous lidocaine for radical middle ear surgery. Thirty-eight patients were observed during this study.

\section{BACKGROUND}

Since the development of the operative field microscope, radical middle ear surgery has become more frequent, with the consequent demands on the anaesthesiologist for more refined techniques that will satisfy the otologist's particular requirements.

The development of the intravenous inhalation technique described herein came about because of dissatisfaction with the previously used techniques. Initially, we were limited to the non-explosive agents because of the use of electrocautery and drill. Considering the surgeon's preference for the addition of epinephrine to the local anaesthetic to be infiltrated in the operative sites, halogenated hydrocarbon agents were excluded because of the hazard of inducing cardiac arrhythmias. In this respect, halothane has been particularly incriminated, ${ }^{1}$ but studies with fluroxene ${ }^{2}$ and methoxyflurane ${ }^{3}$ have suggested that these drugs may also sensitize the myocardium.

In this clinic, the combination of thiopental, meperidine, and nitrous oxide had gained the widest acceptance in middle ear surgery. Owing to the high dose schedule of the narcotic given, and to the protracted time necessary for these procedures, respiratory depression was not infrequently encountered. Children and geriatric patients were especially prone to these narcotic-induced impairments, and their immediate recovery period was prolonged.

A technique incorporating curare-like drugs to approach full relaxation was also unsatisfactory. The need to observe facial muscle contractions, if the surgeon unintentionally manipulated the seventh cranial nerve, mitigated against a drug which could compromise the activity of the myoneural junction.

"Bucking" and coughing, when the operator repositioned the patient's head, or when the final head dressing was applied, were disconcerting. Unless deep stages of anaesthesia were obtained with the previously mentioned techniques, there was little evident depression of laryngo-tracheal reflexes.

-Dr. Aldrete was a Resident, Department of Anesthesia, University Hospitals, Cleveland, Ohio. Present address: University of Colorado Medical Center, Denver, Colorado. Dr. Frazer is an Instructor, Department of Anesthesia, Western Reserve University, School of Medicine, Cleveland, Ohio. 


\section{Histony}

The intravenous use of local anaesthetics for the relief of pruritus ${ }^{4}$ and pain ${ }^{5}$ has been described and clinically used for over two decades. Intravenous procaine was evaluated by Keats and his associates, who found no obvious advantages over then current standard techniques. ${ }^{6}$ Lidocaine was administered intravenously by Gilbert, Hanson, Brown, and Hingson in $1951,{ }^{7}$ and thereafter further reports of extensive clinical series appeared in the literature..$^{8,9}$ In more recent years, Steinhaus and Howland ${ }^{10}$ defined the technique of intravenous lidocaine-nitrous-oxide-thiopental for general anaesthesia. Steinhaus and Gaskin $^{11}$ emphasized the advantage of lidocaine as a cough reflex suppressant.

\section{METHODS}

Most of the 38 patients in our series were premedicated with an appropriate narcotic, barbiturate, and belladonna combination. An occasional patient received promethezine hydrochloride, combined with narcotic and belladonna preparations.

The anaesthetics were administered by closely supervised anaesthesiology residents.

A dependable venoclysis was secured by an indwelling polyethylene catheter inserted into one of the forearm veins.

In the immediate preinduction period, a 0.2 per cent solution of lidocaine was infused at the rate of approximately $20 \mathrm{mg} . / \mathrm{min}$. ( $150 \mathrm{drops} / \mathrm{min}$.) for five minutes. Anaesthesia was then induced with a "sleep dose" of 2 per cent thiopental (100-300 mg.). After a full paralysing dose of succinyl-di-choline (60$100 \mathrm{mg}$.), topical spray of the larynx and trachea was performed with a 4 per cent solution of cocaine, followed by endotracheal intubation.

Following intubation, spontaneous respiration was allowed to return. Throughout the procedure the patient breathed a mixture of nitrous oxide and oxygen (75-25\% concentration) in a semi-closed circuit, by means of carbon dioxide absorption. A cardioscope was attached to the patient for continuous cardiac monitoring.

Lidocaine was infused continually but in gradual decrements during the operative procedure. Doses were arbitrarily based on one-hour intervals and on the patient's response. Up to $700 \mathrm{mg}$. were administered in the first hour, followed by approximately a 40 per cent decrease in each succeeding dose.

The infusion rate was temporarily increased when a more intense surgical stimulus could be anticipated. The lidocaine infusion was discontinued 10 to 15 minutes prior to the end of the operation.

Thiopental, in addition to the induction dose, was also given in small doses (30-50 mg.) immediately preceding the skin incision and at the time of more intense operative manipulation. An altered respiratory pattern was a valuable forewarning sign to indicate the need for supplementary doses of the barbiturate.

In obviously anxious or undermedicated subjects, the anaesthetic was reinforced with minimal doses of intravenous meperidine $(10-20 \mathrm{mg}$.). The complementary doses of the narcotic were necessary most often during the early 
induction period and less commonly during the first hour of surgery. There was no comparison between the small amounts used in this programme and the larger doses necessary in the "classic" thiopental-narcotic-nitrous-oxide technique. In this series, the barbiturate supplements were similarly small.

Robust young patients who remained in very light planes of anaesthesia were occasionally encountered. To avoid untoward movements in these subjects, a single non-paralysing dose of gallamine triethiodide (20-30 mg.) was incorporated at the onset. This allowed time for the lidocaine to obtain its full anaesthetic effect.

\section{ResULts}

Our group of 38 patients consisted of 14 males and 24 females, including five children younger than 12 years of age. The ages varied from 6 to 60 years.

All our patients were included within groups I or II of the A.S.A. physical status classification. Middle ear disease was their primary diagnosis. Concomitent diseases diagnosed included hypertensive cardiovascular disease in three subjects, obesity in two, and hypothyroidism and chronic bronchitis in one case each.

The children were separated from the adult group because of the distinct difference in the dosage schedule pattern and in their altered reaction to the intravenous lidocaine anaesthetic. The statistics, therefore, included only the 33 adults in our series.

The induction doses of thiopental ranged from 80 to $450 \mathrm{mg}$., with an average of $250 \mathrm{mg}$. Barbiturate supplementation was necessary in 31 patients. The dose ranged from 20 to $450 \mathrm{mg}$., with an average of $110 \mathrm{mg}$.

The operative procedures averaged two hours, fifteen minutes in duration, with a range of one to four hours. Of the five cases lasting one hour or less, the average total dose of lidocaine was $325 \mathrm{mg}$. In 18 procedures lasting two hours, an average of $515 \mathrm{mg}$. of lidocaine was infused in the first hour and $208 \mathrm{mg}$. in the second hour. This latter represents a mean reduction of 59 per cent. In six cases lasting three hours, the average dose schedule of lidocaine was as follows: $480 \mathrm{mg}$. during the first hour, $385 \mathrm{mg}$. the second hour, and $85 \mathrm{mg}$. the third hour. The mean reduction in dosage was 20 per cent and 75 per cent respectively, in the latter periods. The anaesthetic lasted up to four hours in four cases. The average doses of lidocaine given in successive hourly periods were: $525 \mathrm{mg}$., $375 \mathrm{mg}$., $325 \mathrm{mg}$., and $200 \mathrm{mg}$. These figures represented a progressive reduction over the preceding hour of 28 per cent, 13 per cent, and 38 per cent respectively (Figure 1).

In 25 subjects given supplemental meperidine, the total dose varied from 20 to $40 \mathrm{mg}$. In five subjects given supplemental gallamine triethiodide, the dosage was from 20 to $60 \mathrm{mg}$. in a single injection.

Clinical observations recorded during anaesthesia included evaluations of cardiovascular and neuromuscular alterations.

The blood-pressure variation from the preoperative control level showed a maximum increase of $40 \mathrm{~mm}$. $\mathrm{Hg}$ in one case and a maximum decrease of $40 \mathrm{~mm}$. $\mathrm{Hg}$ in another case. The average fluctuation was \pm 4 per cent of the patient's control blood pressure. 


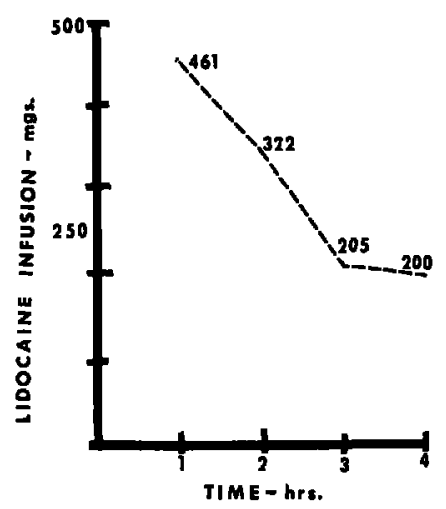

Ficure 1. Average doses of lidocaine infused on an hourly interval basis.

The pulse varied within a narrow range. The average alteration was \pm 10 per cent of the control values.

Electrocardiographic evidence of minor alterations in rhythm or rate were noted in five cases (14\%). One instance of each of the following alterations were recorded: premature ventricular contractions, biphasic $P$ wave, A-V nodal rhythm, moderate bradycardia, and diminished QRS complex voltage. Atropine sulphate $0.2 \mathrm{mg}$. intravenously restored a normal rate in the one case in which mild bradycardia was noted. Increasing the respiratory tidal volume promptly restored the cardiac mechanism to a sinus rhythm in the instance of premature ventricular contractions and nodal rhythm. The remaining two arrhythmias were not treated. Deleterious effects were not apparent clinically.

Minimal involuntary movements occurred during anaesthesia in ten younger subjects. These transient movements were not considered to be preconvulsive in nature and were confined largely to the extremities. They were not of sufficient magnitude to distract the surgeon and were usually related to coincidental surgical stimuli.

\section{Discussion}

During our review of this series of cases we were impressed with the stability of the patients' vital signs. We were particularly watchful for any adverse effect of intravenous lidocaine on the heart. Cardiovascular collapse and depression of myocardial rhythmicity have long been associated with high blood levels of local anaesthetic drugs. The "quinidine-like" action of lidocaine described by Weiss ${ }^{12}$ reinforced our impression that bradycardia and prolongation of electrical conductivity should be avoided. These theoretical hazards were not noted in our cases. There was a trend toward a moderate elevation of blood pressure, probably coincidental with the light planes of anaesthesia encountered."

Gross respiratory depression was not apparent in our patients during either

-The benign cardiac course with intravenous lidocaino-nitrous-oxide anaesthesia has since been observed in over 120 patients undergoing other surgical procedures. 
anaesthesia or the recovery phase. The respiratory excursions were sufficiently vigorous that assistance was not necessary even in prolonged cases.

Most patients were alert and responsive immediately after the surgical dressing was applied. They responded lucidly to questions. Some patients exhibited a euphoric mood while others appeared frankly inebriated. The patients, in most instances, were able to transfer themselves from the operating table to their beds.

The advantage of intravenous lidocaine in suppressing laryngotracheal reflexes was most evident at the termination of the operation. The usual pattern of emergence in these cases was one of high tolerance to the endotracheal tube. At this point most patients were almost awake, but coughing was minimal or absent despite the head motion necessary to apply the pressure head dressing. The emphasis placed by Steinhaus and Gaskin on the particular quality of intravenous lidocaine to minimize laryngotracheal sensitivity ${ }^{11}$ was confirmed in our patients.

A survey of lidocaine-nitrous-oxide anaesthesia by Phillips et al. ${ }^{13}$ reported no significant postoperative analgesic effect of these drugs. Occasionally our patients reported a transitory analgesia when questioned in the immediate recovery period.

Postoperative nausea or emesis was not encountered in our series. A return to a full liquid diet in four hours and to regular meals on the following day was the rule. The anticipated high incidence of nausea in the postoperative period after middle ear surgery was happily avoided.

We were impressed that children reacted in an unpredictable manner to this technique. Some children remained in very light planes of anaesthesia despite doses of lidocaine which approached toxic range. Some young patients showed marked evidence of susceptibility to the toxic central nervous system effects of lidocaine. Two of six children developed localized muscular "twitching" during anaesthesia. We abandoned this technique in patients under 15 years of age early in our series.

\section{SUMMAFY}

A technique of anaesthesia for radical otological surgery is described. The benefits of lidocaine as an intravenous anaesthetic agent in conjunction with nitrous oxide have been suggested for this particular operation in 33 patients. The stability of the cardiovascular system, the obtunding of laryngotracheal reflexes, and a rapid recovery without nausea or other deleterious side-effects were noted.

\section{RÉSUMÉ}

Comme la chirurgie radicale de l'oreille moyenne se pratique de plus en plus souvent, on s'est hâté de perfectionner des techniques d'anesthésie spécialement adaptées à ces interventions.

Dans notre clinique, la lidocaïne intraveineuse combinée au protoxyde d'azote s'est avérée une méthode satisfaisante d'anesthésie générale, si on complète par de petites doses de pentothal et de narcotiques.

Cette technique a présenté certains avantages, par comparaison aux méthodes ordinaires utilisées antérieurement. Elle permet l'usage d'instruments électriques 
et, de plus, l'infiltration de solutions d'adrénaline dans la plaie opératoire sans exposer le malade aux arythmies associées aux hydrocarbures halogénés. Cette méthode prévient aussi la dépression respiratoire et la lenteur du réveil que l’on rencontre lorsqu'on administre de fortes doses d'opiacés ou de barbituriques. Le besoin d'observer les mouvements des muscles de la face interdit de compter sur de fortes doses de myorésolutifs.

Nous exposons les résultats de notre expérience sur 33 cas. Après l'induction au Pentothal, nous pratiquons l'intubation à l'aide de succinylcholine. La lidocaïne par voie veineuse a été injectée d̀ doses décroissantes: en moyenne 450 milligrammes la première heure, puis 322,205 et 200 milligrammes respectivement durant les heures suivantes. On a dú compléter par une dose minime de pentothal chez 31 malades, et 25 one reçu un narcotique.

Nous avons anesthésié de cette façon cinq enfants de 4 à 13 ans; nous ne les incluons pas dans ce rapport à cause des réactions tellement différentes et imprévisibles qu'ils ont présentées au cours de ces anesthésies.

On a observé attentivement le système cardio-vasculaire et il n'y eut aucune anythmie sévère ou hypotension importante.

Dix malades ont présenté des mouvements localisés involontaires, de nature non convulsive. Ces derniers n'étaient pas particulièrement troublants et on a pu les contrôler rapidement par une anesthésie plus profonde.

Il n'y eut pas de nausées et de vomissements postopératoires.

Nous avons été impressionnés par l'abolition des réflexes laryngo-trachéaux et la haute tolérance au tube endotrachéal, même au cours des mouvements de la tête qu'on doit effectuer durant ces cas.

\section{REFERENCES}

1. ANDERSEN, N. \& Johansen, S. H. Incidence of Catecholamine Induced Arrhythmias During Halothane Anesthesia, Anesthesiology. 24: 51 (1963).

2. Councrl of Drugs. An Inhalation Anesthetic, Fluroxene. J.A.M.A. 186: 325 (1963).

3. JacQues, A. \& Hudon, F. Effect of Epinephrine on the Human Heart During Methoxyflurane Anaesthesia. Canad. Anaesth. Soc. J. 10: 53 (1963).

4. Lundy, J. S. Clinical Anesthesia. Philadelphia: W. B. Saunders Co. (1942), p. 391.

5. Gormon, R. A. Intravenous Novocain for Analgesia in Burns. Canad. M.A.J. 49: 478 (1943).

6. Keats, A. S.; De'Allessandro, G. L.; \& Beecher, H. K. A Controlled Study of Pain Relief by Intravenous Procaine. J.A.M.A. 147: 1761 (1951).

7. Gilbert, C. R. A.; Hanson, K. R.; Brown, A. B.; \& Hingson, R. A. Intravenous Use of Xylocaine. Anesth. \& Analg. 30: 301 (1951).

8. DeClive-Lowe, S. G.; Gray, P. W. S.; \& North, J. Succinylcholine and Lignocaine by Continuous Intravenous Drip. Report of 1000 Administrations. Anaesthesia. 9: 94 (1954).

9. ZIRONDOLI, A. Xylocaine Endovenosa in Anestesia Generale. Chirurgia. 8: 72 (1953).

10. Strenniaus, J. E. \& Howland, D. E. Intravenously Administered Lidocaine as a Supplement to Nitrous Oxide-Thiobarbiturate Anesthesia. Anesth. \& Analg. 37: 40 (1958).

11. Steinhaus, J. E. \& Gaskin, L. A Study of Intravenous Lidocaine as a Supplement of Cough Reflex, Anesthesiology. 24: 285 (1963).

12. WeIss, W. A. Intravenous Use of Lidocaine for Ventricular Arrhythmias. Anesth. \& Analg. 39: 369 (1960).

13. Phulutp, O. C.; Lyons, N. B.; Harkus, L. D.; Nelson, A. T.; Graff, T. B.; \& Frazier, T. M. Intravenous Lidocaine as an Adjunct to General Anesthesia. Anesth. \& Analg. 39: 317 (1960). 